$5-18-2017$

\title{
An Assessment of Factors Important to Legislators in Budget Decisions; How Much Impact Can Agencies Have?
}

Arvy Smith

Jason Jensen

University of North Dakota, jason.jensen2@UND.edu

How does access to this work benefit you? Let us know!

Follow this and additional works at: https://commons.und.edu/pssa-fac

Part of the Public Affairs, Public Policy and Public Administration Commons

\section{Recommended Citation}

Arvy Smith and Jason Jensen. "An Assessment of Factors Important to Legislators in Budget Decisions; How Much Impact Can Agencies Have?" (2017). Political Science \& Public Administration Faculty Publications. 7.

https://commons.und.edu/pssa-fac/7

This Article is brought to you for free and open access by the Department of Political Science \& Public Administration at UND Scholarly Commons. It has been accepted for inclusion in Political Science \& Public Administration Faculty Publications by an authorized administrator of UND Scholarly Commons. For more information, please contact und.commons@library.und.edu. 
An Assessment of Factors Important to Legislators in Budget Decisions;

How Much Impact Can Agencies Have?

\begin{abstract}
Budget deliberations represent a dynamic interaction between many actors, including agency officials and legislators. There may be opposing perceptions about the relative importance of various types of information and there are likely many priority factors that legislators base their decisions on, which budget officials may, or may not, have the ability to impact or control. Through a survey of state legislators we first determined the relative importance of 27 factors in approving budget proposals. We compared these ratings with the assessments of both budget / fiscal analysts, and agency budget officials, who were also asked which of the 27 factors they perceived as important to legislators. Agency officials were also asked to rate the degree that they can impact each of the 27 factors. We considered how the difference in party affiliation of legislators relates to the type of information they view as important in budget decisions. We then compared the importance ratings of legislators with the impact ratings of budget officials, which led to some recommendations aimed at agency officials.
\end{abstract}




\section{INTRODUCTION}

In most government jurisdictions, each budget cycle comes with the ritual of agency directors, accountants and program managers shifting their focus from their routine duties to the important process of budget strategy and preparation. Budget actors from both the legislative and executive side interact with stakeholders and interest groups in a dynamic interaction to develop the budget proposals considered by legislatures. Despite the efforts of agency officials in developing their requests, the legislature may approve funding for programs that were never requested or even envisioned, the executive never considered or was made aware of, and powerful interest groups and lobbyists did not represent. Conversely, agency officials and other interests may actively push a proposal that does not get approved by legislators. These two extremes demonstrate that the decision making behavior of legislators, particularly related to budgeting issues, is an important area of inquiry.

There is a fairly rich tradition in political science that considers the behavior of legislators and of legislative institutions, such as Kingdon's (1989), analysis of congressional decision-making and the earlier work of Davidson (1969) and Froman (1967). The above researchers advanced knowledge related to the participants in congressional decision-making, as well as the environment, structure, and process. However, for public administrators, these studies provide little guidance as to how they can bring the most appropriate and meaningful information to legislators for consideration. In fact, there has been sparse research considering the decision making calculus of legislators related to budget proposals, and even less research relating to the relative impact that agency actors can have on factors important to legislators.

There have certainly been many correlates of budget success presented and discussed in the public administration literature, ranging from factors in the external environment to more interpersonal factors. Factors such as the economy, the budget process itself, and the relationships between the 
governor and the legislature all have great impact on whether budget proposals are favorably considered by the legislature (Rubin 2010). State agency personnel have little or no control over these factors, but other factors may be controllable. Identifying these factors could lead to effective strategies, and a higher probability of receiving favorable consideration, which represents both our purpose and contribution.

The core research question of the current study is: What factors are most important to legislators in approving budget proposals (we call importance)? But the primary purpose of the study is to consider the more pragmatic question for public administrators: What is the degree that agency budget officials can impact the factors that have the most importance to legislators?

We address the first question by reporting on the results of surveys of legislators, budget analysts from the legislative and executive sides, and agency budget officials. The relative importance of many factors that can be used by legislators in approving budget proposals is assessed, from the perspectives of these three types of actors. Thus, we are able to compare importance across factors and the perceptions of importance across groups, and begin to analyze reasons for any differences.

The second question is addressed by having respondents identify the factors that agency personnel can impact most. This allows us to compare importance to impact. Finally, we go a step further by considering how the party affiliation of legislators can impact the type of information they value in making decisions. This is only one of many potential contextual variables.

Because there is a dearth of research related to our purpose and research questions, our study is largely exploratory. We will, however, create a context by first discussing some of the relevant literature related to the topic of budgetary decision making as well as agency personnel impacting legislators in budget processes. We will then discuss the methods used in the study before reporting on the results and discussing implications.

\section{Budget Interactions between Agency Officials and Legislators}


A discussion of the determinants of budgetary outcomes typically starts with a structural focus on the incremental nature of budgetary decisions, which has been well established (Davis et al.1966, 1974; Wildavsky 1964). Such a deterministic view implies less room for decision making on an individual level, but instead describes an inertial system with standard operating systems based in bureaucracy. However, within these structures allowances have been made for changes - sometimes significant - that typically are initiated by events outside of the budgeting process (True 2000).

A behavioral decision model is not in opposition to the structural approach, but can supplement it. Such a model has a basis in the bounded rationality tradition of Simon (1957, 1972). In public budgeting, this perspective has evolved into a microbudgeting focus, which considers actors and their respective strategies (Thurmaier 1995; Thurmaier and Willoughby 2001). Although an evolving literature, with regard to informing public administrators about effective budget techniques, it is limited.

Agency budget actors must consider the budget process and environment and, according to Stillman (2005), their most effective strategies are to document need and the ability to save money. Rubin (2010) provides further detail on agencies' strategies including ways to make agency requests more urgent or necessary than other requests, tactics to make requests seem cheap or cost effective, linking proposals to priorities of powerful players or legislators themselves, and finally, tactics to lessen the competition for funding. This work provides some guidance to agency budget officials who are attempting to get budget proposals passed. However, it is not based on direct empirical evidence garnered from legislators, or other budget actors, about what they consider important in the budget process.

There is an existing literature related to the impact of various actors and institutions on the budgeting process and outcomes, often with U.S. state governments as the unit of analysis. The prevailing wisdom in public administration is that budget decisions are impacted by a variety of 
different actors (i.e., agency officials, legislative and executive analysts, interest groups, individuals and courts), as well as the budget process itself and the economic environment (Stillman 2005). There is a rich history of research, also on the state governmental level, analyzing determinants of budget outcomes; results have shown that economic and demographic variables are more predictive than political variables (Dye 1966; Hofferbert 1966; Dawson 1967).

Of the studies considering the impact of institutional and individual actors at the state level, there has been a lot of emphasis on the relative impact of executives and legislatures on budget outcomes. Perhaps the classic study that considered the methods used by agency officials to influence budget decisions of legislators was Sharkansky's (1968) examination of 592 major agency budgets for one budget period in 19 different states. He considered agency budget requests, gubernatorial recommendations, and final legislative appropriations. Sharkansky found gubernatorial support a critical ingredient in budget success of individual agencies and that the more agencies request the more they receive (acquisitiveness). His conclusions were that the governor had more power related to budgeting than legislatures. He also noted that various economic factors are important because they impact both the Governor's recommendations and legislative action on budgets.

Later attempts to replicate Sharkansky's methods led to somewhat different conclusions. Moncrief and Thompson (1980) concluded that governors had the upper hand under conditions of unified government but under divided government legislatures were not as likely to defer to the governor, a result that Clark $(1997,1998)$ generally found support for using data from the 1990s. Thompson (1987) found legislatures less likely to defer to the governor when he used Sharkansky's methods in a later time period (1978-1980). Thompson stressed that economic conditions were different during the time period of his study, compared to Sharkansky's, and reminded us again that economic conditions are important to consider when studying budget outcomes. He also stressed the importance of considering the degree of agency professionalism and gubernatorial influence, both of 
which are factored into the current study. Overall, one could tentatively conclude that legislatures do tend to defer to the governor, although perhaps not as much as times past, and not as much under divided government.

A connected research stream also considers the relative impact of the governor versus the legislature, but using the primary research approach of surveys rather than examining budget documents. Abney and Lauth $(1987,1998)$ surveyed budget officials in the 1980s and 1990s, finding a large decrease in the perception of the gubernatorial influence between time periods, leading them to question executive dominance over state budgeting outcomes (Abney and Lauth 1998). However, the debate is far from being over, since Goodman (2007), also surveying budget analysts, found that they perceived the governor, not the legislature, to benefit from the most recent power shifts. This conclusion was supported by a more extensive analysis by Dometrius and Wright (2010).

The Abney and Lauth $(1987,1998)$ surveys of state budget officials also considered broader perceptions of budget outcomes; particularly, and closest to the objective of the current study, agency strategies that can lead to successful outcomes. They measured perceptions about factors that influenced governors' support for agency budget requests. Factors judged most important were the ability of an agency to demonstrate need, the nexus between agency requests and gubernatorial priorities, program efficiency and effectiveness, and agency acquisitiveness. All of the above factors are controllable to some extent by agencies. But, the factor that is most controllable, of course, is acquisitiveness. The current study goes further in considering perceptions about importance from a broader set of actors, and also considers the degree that agencies can impact budget outcomes.

Rather than considering influence over budgeting outcomes, Duncombe and Kinney (1987) considered how agency officials, executive budget analysts and legislative analysts defined agency budget success. Respondents defined budget success in many ways, including obtaining sufficient funds to meet agency needs and maintain agency programs, maintaining good relationships with 
legislative and executive budget staff, gaining flexibility in using funds, and good budget implementation. Perhaps surprising for those who believe in the budget maximizing bureaucrat model (Niskanen 1971), the appropriation amount compared to the previous budget or the budget request was not the most important indicator of success. Not surprising was their finding that economic and fiscal conditions have a great impact on how agencies approach the budget process and define success, a point supported by Forsythe (2004). He added the extent of changes proposed, incentives for cooperation or competition among leaders, and the political calendar or timing of elections of the involved players as factors that consistently affect budget dynamics. Although informative related to perceptions or likelihood of success, the purpose of these research projects was not to study successful techniques agency officials can use to achieve budget success, however defined.

Another line of inquiry in public administration, albeit sparse, that is related to the interactions of bureaucrat agents and legislative principals is the interpersonal power literature. When agents attempt to influence principals, they are attempting to exercise power in order to get their own way. Jensen (2007) considered influence tactics used in structured policy decision groups, which in many ways could include appropriations committees. As a framework he relied on the rich literature on interpersonal power in the organizational behavior literature, finding that rational persuasion and charisma were the most effective techniques used out of those studied. A follow-up study by Stenstrom and Haycock (2014), specific to budgeting choices, also considered how interpersonal influence tactics can impact outcomes. They found that the tactics "authority," and "consistency and commitment," were important. Particularly important was "liking," which was defined as "a mutual affinity between the target and agent" (Stenstrom and Haycock 2014, 4).

The tactic of "liking" has obvious ties to relationship building and maintenance and links into research by other public administration scholars, who have given more direct prescriptions for budget officials working with politicians. In fact, some recommend that budget officers become politicians 
themselves, engaging in the cultivation of client groups, focusing on building confidence and forming relationships with appropriations committees, and developing political skills that would allow the exploitation of budgetary opportunities (e.g., Davis, Dempster, and Wildavsky 1966, 1974; Wildavsky and Caiden 2004). These authors stress becoming a politician as being more important than demonstrating efficiency.

Budgeting is synonymous with policy making (Wildavsky 1988). Thus, the policy literature can be somewhat informative related to legislative decision making. Some issues receive more attention because they reach a level of salience, forcing legislators to consider them carefully. The presence of issue salience (e.g., Baumgartner and Jones 1993) in budgetary situations creates the possibility that agency officials could benefit from taking advantage of policy bandwagons when proposing expenditure increases, or even reductions. Activism on the part of constituents and interest groups has become commonplace in legislatures from the U.S. Congress on down to city councils, and is related to salience. It is sometimes remarkable how issues revolve around individual actors or circumstances, reach the threshold, are placed on the public agenda, and are passed into law amidst a bandwagon flurry of attention and support. At times, even one constituent can make a difference. Clearly, agency officials can benefit by recognizing when issues are ripe for consideration by legislators and what direction the bandwagon might be leading them.

In some ways, when agency officials attempt to influence their politician principals, there is also a link to the literature on lobbying. Thus, some insight can be gained from considering successful techniques that lobbyists use when interacting with members of Congress. Wolpe and Levine (1996) report that the five most important commandments for lobbyists are: tell the truth, never promise more than you can deliver, know how to listen, work with staff, and don't spring any surprises. These common sense approaches can certainly apply to bureaucrats working with the executive office and 
legislators in getting their budget proposals approved, and are perhaps indicative of budget success. But again, the factors were not derived directly from asking legislators themselves.

Although researchers have done very important work related to budget interactions and dynamics, they have not directly considered factors important to legislative budget success by asking legislators themselves, nor have they considered the degree that agency officials can even have an impact on these factors.

\section{METHODS}

The sampling frame employed in this study consists of public officials within a U.S. state. In this particular state, the executive branch, through the governor and budgeting office, is responsible for developing the budget process and submitting the governor's budget plan to the legislature. Legislators, by law, spend a period of time reviewing the governor's proposal, as well as many other budget proposals included in bills submitted to the legislature. Approval of final budget appropriations for state agencies often occurs in the final hours of the last legislative day. There is a balanced budget requirement, meaning that there can be debt for long term assets, but there must not be a negative general fund balance.

Budget guidelines are provided to state agency budget officials. Budgets are submitted to the budgeting office where they are reviewed and prepared for inclusion in the governor's budget plan. Agency budget officials then present their budget proposals to the legislature.

Sample

Surveys were administered to three groups of respondents:

1) Legislators that have served on appropriations committees during the last three legislative sessions. Legislators were limited to those serving on appropriations committees because these committees make recommendations to the full legislative body regarding passage of 
appropriations bills and, for the most part, their recommendations are accepted by their respective chamber.

2) Legislative and executive fiscal / budget analysts.

3) Agency budget officials who have served in their position within the last three legislative sessions. Agency budget officials were defined as the person in the state agency who is most responsible for the budget strategy for the agency. In smaller agencies this may be the agency director; in others it could be the deputy or assistant director, the chief financial officer or a separate legislative liaison that approves all budget testimony of the agency.

\section{Survey Instruments}

The purpose of this study was to identify: 1) the factors that are most important to legislators in approving budget proposals and 2) which of these factors agency personnel can impact the most. With these goals in mind, the surveys were developed through the following steps:

1) Open-ended interviews were conducted with key budget experts from the three categories agency budget officials, legislators, and budget analysts. Interviewees were asked to identify the most important factors that legislators use in deciding on budget proposals. The interviewer, who was one of the authors, recorded responses. Responses were then compared across interviewees and a comprehensive list of factors was derived.

2) The related literature was then used to refine the list by adding or subtracting factors. A total of 27 factors were identified that could potentially influence legislative budget decisions.

3) Three distinct, but overlapping, surveys were developed using the list of factors.

4) The surveys were piloted with two legislators, a legislative fiscal analyst, and a budget analyst. They provided feedback both on the clarity and design of the instrument as well as opinions about any aspect of the survey that could become controversial. The surveys were then refined into final form. 
The 27 factors are contained in Table 1. Following is a description of the survey that was developed for each respondent group:

1) Legislator Survey: The survey distributed to legislators contained two sections. First, they were asked to rate how important each of the 27 factors was to their decision to approve a budget proposal. The response anchors were 1 and 6, ranging from least important to most important, with an option for "don't know" or "not applicable.” Survey instructions had to vary according to the type of respondent. In section 2 of the survey, some demographic information was collected: Number of legislative sessions served on appropriations (more than 3 / 3 or less); House membership (House / Senate); and party affiliation (Democrat / Republican).

2) Analyst Survey: Legislative and executive budget analysts received the identical survey as outlined above for legislators, except they were instructed to rate how important each of the factors appears to be in legislators' decisions to approve a budget proposal. Section 2 only contained one question asking them how many legislative sessions they have served as a budget analyst (more than 3 / 3 or less).

3) Budget Official Survey: The survey given to budget officials contained three sections. Section 1 was identical to the first section of the legislator and analyst surveys. Officials were asked to rate how important each of the 27 factors appears to be in legislators' decisions to approve a budget proposal. In section 2, they were asked to rate how much impact or control they felt they could have on each of the 27 factors (1-6, least impact to most impact, with an option for "don't know" or "not applicable"). In section 3, they were asked how many legislative sessions they have served as a budget officer (more than 3 / 3 or less). 
In completing the surveys, all respondents were instructed to assume the state was not experiencing a budget shortfall and that the overall state budget would tolerate a moderate $(5 \%$ per year) general fund increase in expenditures. We did this to attempt to control the economic conditions factor, which the literature supported as important to budget decision making. We decided to make it a constant across respondents rather than to assess it directly as a factor.

We anticipated that survey response rates could be an issue, particularly for legislators, for a variety of reasons, including politics. Thus, the survey process was developed to ensure total anonymity to respondents. Support was obtained for the survey from the chair of the committee responsible for legislative management, and that support was indicated in the cover letter for the survey of legislators. As a result the overall response rate across respondent types was a respectable $64 \%$ (77 of 121 surveyed). The response rates by respondent type were 59\% (29 out of 49 surveyed) for legislators, $67 \%$ for analysts ( 8 out of 12 ) and 67\% for agency budget officials (40 of 60 surveyed). Analysis

This study used descriptive statistics to analyze and rank the mean and standard deviation of importance and impact for each of the 27 factors. Analyses of variance (ANOVA) were used to evaluate whether there were differences in importance ratings across subsets of the respondents. Legislators were further stratified by chamber and party affiliation. In addition we present descriptive statistics comparing the mean of these 27 factors of legislative importance by respondent type to the mean of agency impact on these 27 factors; we did this to determine if there was consistency between legislative importance and the ability of an agency to have an impact.

\section{RESULTS AND DISCUSSION}

Factor Importance to Legislators Across Respondent Types 
Table 1 contains each factor, rank ordered according to overall mean for importance to legislators, across all respondent types (legislators, analysts, and agency budget officials). The factor with the highest mean score (most important) across respondent types is listed first, and so on.

Four of the top factors of legislative importance across all respondent types focused on the worthiness of the proposal - whether it addresses a need, is supported by constituents, results in efficiency in government and is for a program that performs well. Approval of proposal does not put the budget out of balance answers the question "Can we afford it?" And, ranking, agency representative has an existing positive relationship of trust and credibility with the legislator third supports work by other researchers on the importance of relationships (e.g., Duncombe and Kinney 1987). Recall that the survey asks what factors the respondents think are most important to legislators based on their experiences and observations.

\section{Factor Importance to Legislators, by Respondent Type}

Discrepancies arise when responses are considered by respondent type, as indicated in Table 1. Note that budget officials and legislators made up 40 and 29 of the total 77 responses, respectively, so the 8 analysts' responses had much less of an impact on the total means. There was also a lot of consistency between ranks of legislators and budget officials related to the bottom rankings, indicating that some factors are judged less important consistently across respondent type.

To assess the degree of variation in means across the three respondent types, analyses of variance (ANOVA) were conducted for each of the 27 factors. The results are presented in Table 2. 10 of the 27 factors showed a statistically significant difference in means between respondent types. Using a Tukey post-hoc test, we determined which respondent type means were significantly different for each factor. A comparison of the means of these ten factors is contained in Table 3.

Analysts' mean ratings on seven of these ten factors were significantly different from legislators'. With the exception of proposal does not require use of state general fund dollars and 
proposal requires $<\$ 100,000$ from state general fund, analysts' mean scores were lower than legislators' scores. Budget officials were significantly different from legislators on four of the ten factors. And in only one case, proposal addresses a well established need, were analysts and budget officials significantly different.

The observed differences are likely related - at least in part - to different perspectives that each respondent type brings to the process, as well as respective roles and the information available. Budget officials track appropriations related to their own agency. They generally do not have the time nor the responsibility to follow budget proposals of other agencies, especially those that aren't in some way related to their own agency. This is related to the traditional view in public administration that agencies are myopic. Although they are involved in conference committees, which debate the proposals late in the process, they may not see some of the negotiations that occur in final deliberations on appropriations where original good intentions get lost in high level strategies or compromises.

Analysts, on the other had, are present at each meeting of an appropriations committee and conference committee. They typically have a portfolio of state agency budgets. This provides them with a broader view of the process compared to budget officials. They field questions from legislators and they see what actually occurs in public hearings.

Finally, legislators attend party caucuses, leadership meetings, lobbyist events, and have "hallway" conversations, where additional information is shared. All legislators are at all full appropriations committee meetings but they are not all at sub-committee meetings where more detailed work occurs on budget proposals. They are more often involved in the final negotiations on proposals. It may be that, at the outset, they intend to consider proposals with well established needs, efficiency in state and local government, proposal validity, supported by constituents, that do not put the budget out of balance and for programs with good past performance. However, in the final 
deliberations these factors may lose out to those factors that analysts indicated they see as important to legislators, such as proposal does not require use of state general fund dollars, proposal requires $<$ $\$ 100,000$ from state general fund, proposal is included in own party leadership strategy and proposal addresses issue with which legislator has had personal experience.

So what does this imply for the novice budget official? Those things that legislators have identified as most important will get serious consideration. Two factors that were ranked high across all three respondent types were, proposal is supported by constituents and agency representative has an existing positive relationship of trust and credibility with legislator. These factors are consistent with the existing literature on this topic, and the latter can be impacted by the official.

Two other factors regarding importance showed interesting results. Proposal is included in budget proposal of the governor and proposal is included in the budget proposal of governor from legislator's own party both ranked in the bottom half at $18^{\text {th }}$ and $22^{\text {nd }}$, respectively. This is inconsistent with Sharkansky's (1968) conclusions that the Governor's support is a critical ingredient in budget success. It is also inconsistent with the notion that state legislatures may defer more to the governor in budgetary decisions, meaning they would be less likely to make changes to the governor's budget, particularly when the governor's party controls the legislature (Clark 1998). However, the results are consistent with Abney and Lauth (1998), who asserted the end of executive dominance in state appropriations. Note that a proposal included in the budget of a governor of a legislator's own party ranked lower than being in the governor's budget in general. Importantly, they were ranked consistently that way by the different respondent types, with the exception of the budget proposal of the governor in general which was ranked $8^{\text {th }}$ by agency budget officials. Of note, the governorship and both the House and Senate were controlled by the same party at the time of the survey. Legislator Characteristics Related to Importance Ratings 
The survey included questions about each legislator's party affiliation and the chamber they serve in. Knowing whether different political parties and chambers consider different factors more important to approval of budget proposals can be useful information to budget officials. The mean and standard deviation of the 27 factors of importance to legislators by political party and chamber are presented in Table 4.

There was a lot of consistency in the ranking of mean scores for the 27 factors between the House and the Senate. There was much less consistency between the Democrats and Republicans in ranking of mean scores of the 27 factors. Democrats' top four factors were agency representative has an existing positive relationship of trust and credibility with legislator, proposal is required as part of national accreditation upon which funding is dependent, proposal addresses issue with which legislator has had personal experience and proposal addresses a well established need. Republicans' top four factors were proposal results in efficiency in state and local government, proposal addresses a well established need, information provided by legislative fiscal analyst validates the accuracy of proposal, and proposal is for program with good past performance. Noting these variances in ranking, we conducted an independent samples t-test for all 27 factors, dividing legislator respondents into House, Senate, Democrat, and Republican to determine if there were significant differences in mean responses for these individual groups. Results indicate that with regard to political party, a significant difference in means was present for 5 of the 27 factors. With regard to chamber, a significant difference in means was present for only 1 factor. Table 5 shows means and t-scores for party and chamber.

The only statistically significant difference in means between the House and the Senate is proposal is required as part of national accreditation upon which funding is not dependent. The Senate scored this higher than the House. Note that during the time of this survey, Republicans had the 
majority membership in both the House and the Senate, possibly explaining the low number of differences between mean scores of the two chambers.

The means for 5 factors were rated differently by Democrats and Republicans. Proposal results in efficiency in state or local government was rated higher by Republicans, while proposal addresses issue with which legislator has had personal experience, proposal is required as part of national accreditation upon which funding is dependent, agency representative has good speaking skills, and agency representative uses technology were all rated higher by Democrats.

Advice to budget officials would be that Republicans value efficiency in government, program needs and past program performance more while Democrats value relationships with budget officials, accreditation, personal experience with an issue, and program need. Although Democrats scored speaking skills and technology higher than Republicans, they were ranked towards the bottom for both parties indicating that both parties value these two items less than other factors. Assessing the Degree of Impact Agencies can have on Important Factors

After rating the importance of the 27 factors, agency budget officials rated each of the same 27 factors related to the amount of control or impact they felt they could have over each. Table 1 contains a column showing the mean for each factor related to agency impact, allowing comparisons with the mean of importance for all three respondent types.

Overall, budget official mean ratings of agency impact on each of the 27 factors were quite high. The top agency impact factors were also rated fairly high in importance by legislators. A comparison of the level of agency impact on the most important factors to legislators can be portrayed with a difference score. Table 6 shows these difference scores for each of the 27 factors. Difference scores that are in the positive direction indicate that legislative importance was rated higher on average than agency impact, and scores in the negative direction indicate that importance was rated as relatively low compared with agency ability to impact. Scores of 0 , or close to 0 , indicate that there 
was continuity between important ratings and the agency impact ratings. Of the six factors that are most important to legislators, the following had positive difference scores: proposal results in efficiency in state or local government, legislative fiscal analyst validates accuracy of proposal, proposal does not put budget out of balance, and proposal is supported by constituents. The following factors had negative difference scores: proposal addresses a well established need, and program with good past performance. Thus, according to these results, agencies would be best served by focusing on substantiating need and performance, which they can control. Overall, agency officials reported that they can impact many of the other factors legislators consider in the legislative appropriations process.

\section{CONCLUSION}

The purpose of this study was to identify factors that are most important to legislators in approving budget proposals and which of these factors agency personnel can impact most. There were not a lot of surprises in the total respondent rankings of the 27 factors. There were however, significant differences in how the individual respondent types scored the 27 factors. An interesting result that should be pursued with future research was related to political party of legislators. Party affiliation of legislators can have an impact on how they consider proposals and a wise agency official could use this result as part of an overall strategy.

Agency budget officials generally feel that they can impact the factors that are most important to legislators. But, there is variation, with some important factors being more open to impact than others. Again, budget officials would be best served focusing on factors important to legislators, that they can also be impact.

This study did not include an analysis of specific budget proposals to determine which factors made each proposal successful. Such a project would be worthwhile, albeit complex. Opinions and recollections of legislators on what is important may not square well with actual measures of 
legislative behavior or outcomes. This could be an important follow up study to see if the factors identified in the current study are actually those that made a difference in approval of a proposal.

Although the governor is a key player in the budgeting process, the scope of this study was limited to the decisions of legislators, since they grant the final spending authority. However, note that two of the factors considered are that a proposal is included in the governor's budget and that a proposal is included in the governor's budget from the legislator's own party. Thus, indirectly gubernatorial power was considered.

One of the narrative comments provided by an agency budget official was, "This process often seems like a game for which I am not allowed to know the rules." The results of this study may give this individual, and other budget officials, encouragement. Despite the many things that are beyond their control, there are some patterns that they can learn and follow in order to have a better chance of a successful budget outcome.

The main shortcoming of the study is that it is essentially a case study of a single state. Due to the complexity of the methodology, which includes creating the sampling frame, developing the surveys, and getting permission to conduct the study, creating a cross-section of states would be difficult. Case studies of states have a rich history in public administration and add to the cumulative knowledge of the field (Jensen and Rodgers 2001). Nonetheless, the question of generalizability becomes important. There is likely a lot of homogeneity across state legislatures related to the processes used to develop budgets. Indeed many of the findings are not only intuitive but are consistent with the literature, which bodes well for generalizability. However, there are likely some state specific differences that have the potential to impact generalizability. For instance, the budgeting method used. Performance based budgeting would necessitate an enhanced focus on performance measures. Future research could utilize the surveys used here and apply them to other governmental jurisdictions, and thereby test the degree that our findings generalize. 


\section{REFERENCES}

Abney, Glenn, and Thomas P. Lauth. 1987. "Perceptions of the Impact of Governors and Legislatures in the Appropriations Process." Western Political Quarterly. 40: 335-342.

Abney, Glenn, and Thomas P. Lauth. 1998. "The End of Executive Dominance in State Appropriations.” Public Administration Review. 58 (5): 388-94.

Baumgartner, Frank R., and Bryan D. Jones. 1993. Agendas and Instability in American Politics. Chicago: University of Chicago Press.

Clarke, Wes. 1997. "Budget Requests and Agency Head Selection Methods.” Political Research Quarterly. 50 (2): 301-16.

Clarke, Wes. 1998. "Divided Government and Budget Conflict in the U. S. States." Legislative Studies Quarterly. 23 (1): 5-22.

Davidson, Roger H. 1969. The Role of the Congressman. New York: Pegasus.

Davis, Otto. A., M. A. H. Dempster, and Aaron Wildavsky. 1966. "A Theory of the Budgetary Process." The American Political Science Review. 60 (3): 529-547.

Davis, Otto. A., M. A. H. Dempster, and Aaron Wildavsky. 1974. "Towards a Predictive Theory of Government Expenditure: US Domestic Appropriations." British Journal of Political Science. 4: 419-452.

Dawson, Richard E. 1967. "Social Development, Party Competition, and Policy." In The American Party Systems: Stages of Political Development, edited by W. N. Chambers and W. D. Burnham, 203-237. New York: Oxford University Press.

Dometrius, Nelson C., and Deil S. Wright (2010). "Governors, Legislators, and State Budgets across Time." Political Research Quarterly. 63(4): 783-795. 
Duncombe, Sydney and Richard Kinney. 1987. “Agency Budget Success: How It is Defined by Budget Officials in Five Western States.” Public Budgeting \& Finance. 7 (1): 24-37.

Dye, Thomas R. 1966. Politics, Economics, and the Public: Policy Outcomes in the American States. Chicago: Rand McNally.

Forsythe, Dall W., 2004. Memos to the Governor. Second Edition. Washington, D.C.: Georgetown University Press.

Froman, Lewis A. 1967. The Congressional Process; Strategies, Rules, and Procedures. Boston: Little, Brown and Company.

Goodman, Doug. 2007. "Determinants of Perceived Gubernatorial Budgetary Influence among State Executive Budget Analysts and Legislative Fiscal Analysts.” Political Research Quarterly. 60 (1): $43-54$.

Hofferbert, Richard I. 1966. "The Relationship between Public Policy ad Some Structural and Environmental Variables in the American States.” American Political Science Review. 60: 7382.

Jensen, Jason L., and Robert Rodgers. 2001. "Cumulating the Intellectual Gold of Case Study Research.” Public Administration Review. 61 (2): 235-246.

Jensen, Jason L. 2007. “Getting One's Way in Policy Debates: Influence Tactics Used in Group Decision-Making Settings.” Public Administration Review. 67 (2): 216-227.

Kingdon, John. 1989. Congressmen's Voting Decisions; $3^{\text {rd }}$ Edition. Ann Arbor, MI: University of Michigan Press.

Moncrief, Gary F., and Joel A. Thompson. 1980. "Partisanship and Purse Strings: A Research Note on Sharkansky." Western Political Quarterly. 33: 336-40.

Niskanen, William A. Jr. 1971. Bureaucracy and Representative Government. Chicago: Aldine Publishing. 
Rubin, Irene S. 2010. The Politics of Public Budgeting: Getting and Spending, Borrowing and Balancing. Sixth Edition. Washington, D.C.: CQ Press.

Sharkansky, Ira. 1968. Agency Requests, Gubernatorial Support and Budget Success in State Legislatures. The American Political Science Review. 62 (4):1220-1231.

Simon, Herbert A. 1957. Models of Man. New York: Wiley.

Simon, Herbert A. 1972. "Theories of Bounded Rationality." Decision and Organization, edited by C. B. McGuire and Roy Radner, 161-175. Amsterdam: North-Holland.

Stenstrom, Cheryl, and Ken Haycock. 2014. "The Role of Interpersonal Influence in Budget Decision Making: The Canadian Public Library Experience.” Administration and Society. OnlineFirst, published on January 9, 2014 as doi: 10.1177/0095399713519091: 1-32.

Stillman II, Richard J. 2005. Public Administration Concepts and Cases. Eighth Edition. Boston: Houghton Mifflin Company.

Thompson, Joel A. 1987. “Agency Requests, Gubernatorial Support, and Budget Success in State Legislatures Revisited.” The Journal of Politics. 49 (3): 756-779.

Thurmaier, Kurt. 1995. "Decisive Decision Making in the Executive Budget Process: Analyzing the Political and Economic Propensities of Central Budget Bureau Analysts.” Public Administration Review. 55: 448-60.

Thurmaier, Kurt, and Katherine G. Willoughby. 2001. Policy and Politics in State Budgeting. New York: M.E. Sharpe.

True, James L. 2000. “Avalanches and Incrementalism.” American Review of Public Administration. $30(1): 3-18$.

Wildavsky, A. B. 1964. The Politics of the Budgetary Process. Boston: Little, Brown. Wildavsky, Aaron. 1988. The New Politics of Budgetary Process. Glenview, IL: Scott, Foresman / Little Brown College Division. 
Wildavsky, A., and N. Caiden. 2004. The New Politics of the Budgetary Process. 5th edition. New York: Pearson-Longman.

Wolpe, Bruce C. and Levine, Bertram J. 1996. Lobbying Congress: How the System Works. Second Edition. Washington, D.C.: Congressional Quarterly, Inc. 
TABLE 1

Mean Ranking of Legislative Importance According to Legislators, Budget Analysts and Budget Officials, and Mean Ranking of Agency Impact According to Budget Officials

\begin{tabular}{|c|c|c|c|c|c|c|}
\hline Factor & & Legislators & Analysts & $\begin{array}{l}\text { Budget } \\
\text { Officials }\end{array}$ & Total & $\begin{array}{l}\text { Agency } \\
\text { Impact }\end{array}$ \\
\hline \multirow{3}{*}{$\begin{array}{l}\text { Proposal is for program that addresses a } \\
\text { well established need }\end{array}$} & Rank & 2 & 15 & 2 & 1 & 4 \\
\hline & Mean & 5.07 & 4.00 & 5.00 & 4.92 & 5.17 \\
\hline & St. Dev. & 0.923 & 0.926 & 0.918 & 0.963 & 0.636 \\
\hline \multirow{3}{*}{$\begin{array}{l}\text { Proposal results in efficiency in state or } \\
\text { local government }\end{array}$} & Rank & 1 & 11 & 7 & 2 & 6 \\
\hline & Mean & 5.28 & 4.25 & 4.79 & 4.92 & 4.89 \\
\hline & St. Dev. & 0.649 & 1.165 & 0.951 & 0.920 & 0.798 \\
\hline \multirow{3}{*}{$\begin{array}{l}\text { Agency representative has an existing } \\
\text { positive relationship of trust and credibility } \\
\text { with legislator }\end{array}$} & Rank & 8 & 6 & 1 & 3 & 3 \\
\hline & Mean & 4.69 & 4.63 & 5.13 & 4.91 & 5.2 \\
\hline & St. Dev. & 1.339 & 0.518 & 0.767 & 1.022 & 0.939 \\
\hline \multirow[t]{3}{*}{ Proposal is supported by constituents } & Rank & 5 & 4 & 4 & 4 & 13 \\
\hline & Mean & 4.76 & 4.88 & 4.95 & 4.87 & 4.29 \\
\hline & St. Dev. & 0.951 & 0.641 & 0.986 & 0.937 & 1.113 \\
\hline \multirow{3}{*}{$\begin{array}{l}\text { Approval of proposal does not put the } \\
\text { budget out of balance }\end{array}$} & Rank & 4 & 12 & 3 & 5 & 19 \\
\hline & Mean & 4.83 & 4.25 & 5.00 & 4.86 & 3.92 \\
\hline & St. Dev. & 1.104 & 1.488 & 0.761 & 1.003 & 1.628 \\
\hline \multirow{3}{*}{$\begin{array}{l}\text { Proposal is for program with good past } \\
\text { performance }\end{array}$} & Rank & 6 & 13 & 5 & 6 & 7 \\
\hline & Mean & 4.72 & 4.13 & 4.92 & 4.77 & 4.85 \\
\hline & St. Dev. & 0.960 & 0.835 & 0.797 & 0.887 & 0.812 \\
\hline \multirow{3}{*}{$\begin{array}{l}\text { Information provided by legislative fiscal } \\
\text { analyst validates the accuracy of proposal }\end{array}$} & Rank & 3 & 7 & 11 & 7 & 16 \\
\hline & Mean & 4.90 & 4.62 & 4.67 & 4.75 & 4.17 \\
\hline & St. Dev. & 1.012 & 0.518 & 0.982 & 0.954 & 1.299 \\
\hline \multirow{3}{*}{$\begin{array}{l}\text { Proposal is included in own party } \\
\text { leadership strategy }\end{array}$} & Rank & 11 & 1 & 18 & 8 & 23 \\
\hline & Mean & 4.54 & 5.38 & 4.39 & 4.57 & 3.59 \\
\hline & St. Dev. & 1.036 & 0.744 & 1.321 & 1.182 & 1.427 \\
\hline \multirow{3}{*}{$\begin{array}{l}\text { Proposal does not require use of state } \\
\text { general fund dollars }\end{array}$} & Rank & 18 & 3 & 6 & 9 & 15 \\
\hline & Mean & 3.97 & 5.00 & 4.90 & 4.56 & 4.2 \\
\hline & St. Dev. & 1.085 & 0.756 & 0.672 & 0.966 & 1.265 \\
\hline \multirow{3}{*}{$\begin{array}{l}\text { Proposal addresses an issue with which } \\
\text { legislator has had personal experience }\end{array}$} & Rank & 12 & 2 & 17 & 10 & 20 \\
\hline & Mean & 4.52 & 5.29 & 4.45 & 4.55 & 3.9 \\
\hline & St. Dev. & 1.022 & 0.756 & 0.986 & 0.999 & 1.465 \\
\hline \multirow{3}{*}{$\begin{array}{l}\text { Proposal clearly helps agency accomplish } \\
\text { its mission }\end{array}$} & Rank & 10 & 22 & 14 & 11 & 2 \\
\hline & Mean & 4.62 & 3.50 & 4.62 & 4.50 & 5.28 \\
\hline & St. Dev. & 0.942 & 0.926 & 1.067 & 1.052 & 0.640 \\
\hline Proposal carries recommendation of "Do & Rank & 14 & 16 & 9 & 12 & 14 \\
\hline \multirow{2}{*}{ Pass" from policy committee } & Mean & 4.24 & 4.00 & 4.68 & 4.44 & 4.24 \\
\hline & St. Dev. & 1.154 & 1.069 & 0.944 & 1.057 & 1.101 \\
\hline
\end{tabular}




\begin{tabular}{|c|c|c|c|c|c|c|}
\hline$\underline{\text { Factor }}$ & & Legislators & Analysts & $\begin{array}{l}\text { Budget } \\
\text { Officials }\end{array}$ & Total & $\begin{array}{l}\text { Agency } \\
\text { Impact }\end{array}$ \\
\hline $\begin{array}{l}\text { Budget presentation by agency } \\
\text { representative is clear }\end{array}$ & $\begin{array}{l}\text { Rank } \\
\text { Mean } \\
\text { St. Dev. }\end{array}$ & $\begin{array}{c}15 \\
4.24 \\
1.215\end{array}$ & $\begin{array}{c}18 \\
4.00 \\
0.756\end{array}$ & $\begin{array}{c}12 \\
4.65 \\
0.975\end{array}$ & $\begin{array}{c}13 \\
4.43 \\
1.069\end{array}$ & $\begin{array}{c}1 \\
5.38 \\
0.740\end{array}$ \\
\hline $\begin{array}{l}\text { Information provided by executive budget } \\
\text { analyst validates the accuracy of proposal }\end{array}$ & $\begin{array}{l}\text { Rank } \\
\text { Mean } \\
\text { St. Dev. }\end{array}$ & $\begin{array}{c}13 \\
4.34 \\
1.261\end{array}$ & $\begin{array}{c}14 \\
4.13 \\
0.641\end{array}$ & $\begin{array}{c}15 \\
4.54 \\
0.996\end{array}$ & $\begin{array}{c}14 \\
4.42 \\
1.074\end{array}$ & $\begin{array}{c}11 \\
4.48 \\
1.176\end{array}$ \\
\hline $\begin{array}{l}\text { Proposal has clear outcome measures } \\
\text { related to its goals }\end{array}$ & $\begin{array}{l}\text { Rank } \\
\text { Mean } \\
\text { St. Dev. }\end{array}$ & $\begin{array}{c}7 \\
4.72 \\
0.996\end{array}$ & $\begin{array}{c}26 \\
3.00 \\
1.195\end{array}$ & $\begin{array}{c}16 \\
4.47 \\
1.037\end{array}$ & $\begin{array}{c}15 \\
4.42 \\
1.140\end{array}$ & $\begin{array}{c}5 \\
5.08 \\
0.774\end{array}$ \\
\hline $\begin{array}{l}\text { Proposal otherwise justified does not } \\
\text { require full time equivalents (FTE) }\end{array}$ & $\begin{array}{l}\text { Rank } \\
\text { Mean } \\
\text { St. Dev. }\end{array}$ & $\begin{array}{c}17 \\
4.07 \\
1.307\end{array}$ & $\begin{array}{c}9 \\
4.50 \\
0.756\end{array}$ & $\begin{array}{c}13 \\
4.65 \\
1.051\end{array}$ & $\begin{array}{c}16 \\
4.42 \\
1.151\end{array}$ & $\begin{array}{c}17 \\
4.03 \\
1.230\end{array}$ \\
\hline Proposal is equitable to all those impacted & $\begin{array}{l}\text { Rank } \\
\text { Mean } \\
\text { St. Dev. }\end{array}$ & $\begin{array}{c}9 \\
4.62 \\
0.979\end{array}$ & $\begin{array}{c}23 \\
3.43 \\
0.976\end{array}$ & $\begin{array}{c}19 \\
4.31 \\
0.863\end{array}$ & $\begin{array}{c}17 \\
4.35 \\
0.966\end{array}$ & $\begin{array}{c}12 \\
4.46 \\
0.720\end{array}$ \\
\hline $\begin{array}{l}\text { Proposal is included in the budget } \\
\text { proposal of the governor }\end{array}$ & $\begin{array}{l}\text { Rank } \\
\text { Mean } \\
\text { St. Dev. }\end{array}$ & $\begin{array}{c}19 \\
3.83 \\
1.441\end{array}$ & $\begin{array}{c}17 \\
4.00 \\
0.926\end{array}$ & $\begin{array}{c}8 \\
4.75 \\
0.981\end{array}$ & $\begin{array}{c}18 \\
4.32 \\
1.240\end{array}$ & $\begin{array}{c}10 \\
4.49 \\
1.254\end{array}$ \\
\hline $\begin{array}{l}\text { Proposal is required as part of national } \\
\text { accreditation upon which funding is } \\
\text { dependent }\end{array}$ & $\begin{array}{l}\text { Rank } \\
\text { Mean } \\
\text { St. Dev. }\end{array}$ & $\begin{array}{c}16 \\
4.21 \\
1.264\end{array}$ & $\begin{array}{c}8 \\
4.50 \\
0.535\end{array}$ & $\begin{array}{c}20 \\
4.28 \\
1.326\end{array}$ & $\begin{array}{c}19 \\
4.28 \\
1.223\end{array}$ & $\begin{array}{c}24 \\
3.42 \\
1.714\end{array}$ \\
\hline Proposal is supported by stakeholders & $\begin{array}{l}\text { Rank } \\
\text { Mean } \\
\text { St. Dev. }\end{array}$ & $\begin{array}{c}22 \\
3.66 \\
1.344\end{array}$ & $\begin{array}{c}10 \\
4.29 \\
0.756\end{array}$ & $\begin{array}{c}10 \\
4.67 \\
1.221\end{array}$ & $\begin{array}{c}20 \\
4.24 \\
1.314\end{array}$ & $\begin{array}{c}9 \\
4.69 \\
1.104\end{array}$ \\
\hline $\begin{array}{l}\text { Proposal requires }<\$ 100,000 \text { from state } \\
\text { general fund }\end{array}$ & $\begin{array}{l}\text { Rank } \\
\text { Mean } \\
\text { St. Dev. }\end{array}$ & $\begin{array}{c}21 \\
3.69 \\
1.137\end{array}$ & $\begin{array}{c}5 \\
4.75 \\
0.886\end{array}$ & $\begin{array}{c}21 \\
4.18 \\
1.023\end{array}$ & $\begin{array}{c}21 \\
4.05 \\
1.094\end{array}$ & $\begin{array}{c}22 \\
3.76 \\
0.998\end{array}$ \\
\hline $\begin{array}{l}\text { Proposal is included in budget proposal } \\
\text { of governor from own party }\end{array}$ & $\begin{array}{l}\text { Rank } \\
\text { Mean } \\
\text { St. Dev. }\end{array}$ & $\begin{array}{c}20 \\
3.76 \\
1.327\end{array}$ & $\begin{array}{c}19 \\
3.88 \\
1.126\end{array}$ & $\begin{array}{c}23 \\
4.00 \\
1.306\end{array}$ & $\begin{array}{c}22 \\
3.89 \\
1.284\end{array}$ & $\begin{array}{c}21 \\
3.90 \\
1.633\end{array}$ \\
\hline $\begin{array}{l}\text { Agency representative has good speaking } \\
\text { skills }\end{array}$ & $\begin{array}{l}\text { Rank } \\
\text { Mean } \\
\text { St. Dev. }\end{array}$ & $\begin{array}{c}24 \\
3.31 \\
1.491\end{array}$ & $\begin{array}{c}20 \\
3.75 \\
0.707\end{array}$ & $\begin{array}{c}22 \\
4.16 \\
1.103\end{array}$ & $\begin{array}{c}23 \\
3.79 \\
1.287\end{array}$ & $\begin{array}{c}8 \\
4.80 \\
1.363\end{array}$ \\
\hline $\begin{array}{l}\text { Proposal is required as part of national } \\
\text { accreditation upon which funding is not } \\
\text { dependent }\end{array}$ & $\begin{array}{l}\text { Rank } \\
\text { Mean } \\
\text { St. Dev. }\end{array}$ & $\begin{array}{c}23 \\
3.45 \\
1.404\end{array}$ & $\begin{array}{c}21 \\
3.63 \\
0.744\end{array}$ & $\begin{array}{c}24 \\
3.28 \\
1.143\end{array}$ & $\begin{array}{c}24 \\
3.39 \\
1.215\end{array}$ & $\begin{array}{c}25 \\
3.06 \\
1.456\end{array}$ \\
\hline
\end{tabular}


Table 1: continued

\begin{tabular}{|c|c|c|c|c|c|c|}
\hline$\underline{\text { Factor }}$ & & Legislators & Analysts & $\begin{array}{l}\text { Budget } \\
\text { Officials }\end{array}$ & Total & $\begin{array}{l}\text { Agency } \\
\text { Impact }\end{array}$ \\
\hline $\begin{array}{l}\text { Agency representative uses technology to } \\
\text { present proposal }\end{array}$ & $\begin{array}{l}\text { Rank } \\
\text { Mean } \\
\text { St. Dev. }\end{array}$ & $\begin{array}{c}25 \\
3.07 \\
1.361\end{array}$ & $\begin{array}{c}24 \\
3.38 \\
0.518\end{array}$ & $\begin{array}{c}25 \\
2.68 \\
1.068\end{array}$ & $\begin{array}{c}25 \\
2.91 \\
1.164\end{array}$ & $\begin{array}{c}18 \\
3.97 \\
1.219\end{array}$ \\
\hline Proposal has support of NCSL & $\begin{array}{l}\text { Rank } \\
\text { Mean } \\
\text { St. Dev. }\end{array}$ & $\begin{array}{c}26 \\
2.38 \\
1.237\end{array}$ & $\begin{array}{c}25 \\
3.29 \\
1.380\end{array}$ & $\begin{array}{c}26 \\
2.67 \\
1.038\end{array}$ & $\begin{array}{c}26 \\
2.60 \\
1.185\end{array}$ & $\begin{array}{c}26 \\
2.14 \\
1.246\end{array}$ \\
\hline $\begin{array}{l}\text { Proposal is supported by legislative } \\
\text { peers from other states }\end{array}$ & $\begin{array}{l}\text { Rank } \\
\text { Mean } \\
\text { St. Dev. }\end{array}$ & $\begin{array}{c}27 \\
2.07 \\
1.033\end{array}$ & $\begin{array}{c}27 \\
2.83 \\
0.753\end{array}$ & $\begin{array}{c}27 \\
2.41 \\
1.047\end{array}$ & $\begin{array}{c}27 \\
2.29 \\
1.030\end{array}$ & $\begin{array}{c}27 \\
1.80 \\
0.997\end{array}$ \\
\hline
\end{tabular}

* Note: The Total column contains the mean across the three groups based on a Likert scale from 1 (least important) to 6 (most important). The mean impact column reflects a Likert scale from 1 (least impact) to 6 (most impact). 
TABLE 2

Analysis of Variance Comparing the Mean Importance Ratings of Legislators, Budget Analysts and Budget Officials

\begin{tabular}{|c|c|c|}
\hline & Overall Mean & F-Score \\
\hline Proposal addresses a well established need & 4.92 & $4.522 *$ \\
\hline Proposal results in efficiency in state or local government & 4.92 & $5.164 * *$ \\
\hline $\begin{array}{l}\text { Agency representative has an existing positive } \\
\text { relationship of trust and credibility with legislator }\end{array}$ & 4.91 & 1.919 \\
\hline Proposal is supported by constituents & 4.87 & .345 \\
\hline Approval of proposal does not put the budget out of balance & 4.86 & 1.921 \\
\hline Proposal is for program with good past performance & 4.77 & 2.902 \\
\hline $\begin{array}{l}\text { Information provided by legislative fiscal analyst } \\
\text { validates the accuracy of proposal }\end{array}$ & 4.75 & .553 \\
\hline Proposal is included in own party leadership strategy & 4.57 & 2.320 \\
\hline Proposal does not require use of state general fund dollars & 4.56 & $11.135 * *$ \\
\hline $\begin{array}{l}\text { Proposal addresses an issue with which legislator } \\
\text { has had personal experience }\end{array}$ & 4.55 & 2.182 \\
\hline Proposal clearly helps agency accomplish its mission & 4.50 & $4.407 *$ \\
\hline $\begin{array}{l}\text { Proposal carries recommendation of "Do Pass" } \\
\text { from policy committee }\end{array}$ & 4.44 & 2.265 \\
\hline Budget presentation by agency representative is clear & 4.43 & 1.996 \\
\hline $\begin{array}{l}\text { Information provided by executive budget analyst } \\
\text { validates the accuracy of proposal }\end{array}$ & 4.42 & .603 \\
\hline Proposal has clear outcome measures related to its goals & 4.42 & $8.782 * *$ \\
\hline Proposal otherwise justified does not require FTE & 4.42 & 2.236 \\
\hline Proposal is equitable to all those impacted & 4.35 & $4.814^{*}$ \\
\hline Proposal is included in the budget proposal of the Governor & 4.32 & $5.550 * *$ \\
\hline $\begin{array}{l}\text { Proposal is required as part of national accreditation } \\
\text { upon which funding is dependent }\end{array}$ & 4.28 & .176 \\
\hline Proposal is supported by stakeholders & 4.24 & $5.542 * *$ \\
\hline Proposal requires $<\$ 100,000$ from state general fund & 4.05 & $3.737 *$ \\
\hline Proposal is included in budget proposal of governor from own party & 3.89 & .275 \\
\hline Agency representative has good speaking skills & 3.79 & $3.844^{*}$ \\
\hline $\begin{array}{l}\text { Proposal is required as part of national accreditation } \\
\text { upon which funding is not dependent }\end{array}$ & 3.39 & .305 \\
\hline Agency representative uses technology to present proposal & 2.91 & 1.651 \\
\hline Proposal has support of NCSL & 2.60 & 1.759 \\
\hline Proposal is supported by legislative peers from other states & 2.29 & 1.716 \\
\hline
\end{tabular}

Note: ${ }^{*} \mathrm{p}<.05 ;{ }^{* *} \mathrm{p}<.01$; The mean importance column reflects a Likert scale from 1 (least important) to 6 (most important). 
TABLE 3

ANOVA Post-Test: Differences between Respondent Types

Proposal addresses a well established need (1)

Proposal results in efficiency in state or local government (2)

Proposal does not require use of state general fund dollars (9)

Proposal clearly helps agency accomplish its mission (11)

Proposal has clear outcome measures related to its goals (15)

Proposal is equitable to all those impacted (17)

Proposal is included in the budget proposal of the governor (18)

Proposal is supported by stakeholders (20)

Proposal requires $<\$ 100,000$ from state general fund (21)

Agency representative has good speaking skills (23)

\begin{tabular}{lll} 
Legislator & Analysts & $\begin{array}{l}\text { Budget } \\
\text { Official }\end{array}$ \\
\hline $5.07^{\#}$ & $4.00^{*} \#$ & $5.00^{*}$ \\
$5.28^{*}$ & $4.25^{*}$ & 4.79 \\
$3.97^{*} \#$ & $5.00^{\#}$ & $4.90^{*}$ \\
$4.62^{*}$ & $3.50^{*}$ & 4.62 \\
$4.72 *$ & $3.00^{*}$ & 4.47 \\
$4.62^{*}$ & $3.43^{*}$ & 4.31 \\
$3.83^{*}$ & 4.00 & $4.75^{*}$ \\
$3.66^{*}$ & 4.29 & $4.67^{*}$ \\
$3.69^{*}$ & $4.75^{*}$ & 4.18 \\
$3.31^{*}$ & 3.75 & $4.16^{*}$ \\
& &
\end{tabular}

Note: * indicates that these two mean scores are significantly different $(\mathrm{p}<.05)$ between the two respondent types marked for that factor. \# indicates that these two mean scores are significantly different $(\mathrm{p}<.05)$ between the two respondent types marked for that factor. Overall factor ranking shown in parentheses. 
TABLE 4

Mean Ranking of Legislative Importance (Legislators Only); Chamber and Party Affiliation

\begin{tabular}{|c|c|c|c|c|c|c|}
\hline Factor & & House & Senate & Democrat & Republican & Total \\
\hline \multirow{2}{*}{$\begin{array}{l}\text { Proposal results in efficiency in state or } \\
\text { local government }\end{array}$} & Rank & 1 & 2 & 7 & 1 & 1 \\
\hline & Mean & 5.22 & 5.44 & 4.89 & 5.50 & 5.28 \\
\hline \multirow{2}{*}{$\begin{array}{l}\text { Proposal is for program that addresses a } \\
\text { well established need }\end{array}$} & Rank & 2 & 1 & 4 & 2 & 2 \\
\hline & Mean & 5.00 & 5.44 & 5.11 & 5.11 & 5.07 \\
\hline \multirow{2}{*}{$\begin{array}{l}\text { Information provided by legislative fiscal } \\
\text { analyst validates the accuracy of proposal }\end{array}$} & Rank & 5 & 3 & 8 & 3 & 3 \\
\hline & Mean & 4.67 & 5.33 & 4.89 & 4.94 & 4.90 \\
\hline \multirow{2}{*}{$\begin{array}{l}\text { Approval of proposal does not put the } \\
\text { budget out of balance }\end{array}$} & Rank & 6 & 4 & 5 & 6 & 4 \\
\hline & Mean & 4.67 & 5.22 & 5.11 & 4.72 & 4.83 \\
\hline \multirow[t]{2}{*}{ Proposal is supported by constituents } & Rank & 4 & 13 & 6 & 9 & 5 \\
\hline & Mean & 4.67 & 4.78 & 5.11 & 4.61 & 4.76 \\
\hline \multirow{2}{*}{$\begin{array}{l}\text { Proposal is for program with good past } \\
\text { performance }\end{array}$} & Rank & 3 & 8 & 11 & 4 & 6 \\
\hline & Mean & 4.67 & 4.89 & 4.56 & 4.78 & 4.72 \\
\hline \multirow{2}{*}{$\begin{array}{l}\text { Proposal has clear outcome measures } \\
\text { related to its goals }\end{array}$} & Rank & 9 & 7 & 12 & 5 & 7 \\
\hline & Mean & 4.61 & 5.00 & 4.56 & 4.78 & 4.72 \\
\hline \multirow{2}{*}{$\begin{array}{l}\text { Agency rep has an existing positive relationship } \\
\text { with legislator }\end{array}$} & Rank & 8 & 5 & 1 & 11 & 8 \\
\hline & Mean & 4.67 & 5.11 & 5.33 & 4.50 & 4.69 \\
\hline \multirow[t]{2}{*}{ Proposal is equitable to all those impacted } & Rank & 7 & 14 & 9 & 10 & 9 \\
\hline & Mean & 4.67 & 4.67 & 4.67 & 4.61 & 4.62 \\
\hline \multirow{2}{*}{$\begin{array}{l}\text { Proposal clearly helps agency accomplish } \\
\text { its mission }\end{array}$} & Rank & 12 & 6 & 15 & 7 & 10 \\
\hline & Mean & 4.39 & 5.00 & 4.44 & 4.67 & 4.62 \\
\hline \multirow{2}{*}{$\begin{array}{l}\text { Proposal is included in own party } \\
\text { leadership strategy }\end{array}$} & Rank & 10 & 16 & 17 & 8 & 11 \\
\hline & Mean & 4.56 & 4.63 & 4.33 & 4.65 & 4.54 \\
\hline \multirow{2}{*}{$\begin{array}{l}\text { Proposal addresses an issue with which } \\
\text { legislator has had personal experience }\end{array}$} & Rank & 11 & 12 & 3 & 12 & 12 \\
\hline & Mean & 4.44 & 4.78 & 5.22 & 4.28 & 4.52 \\
\hline \multirow{2}{*}{$\begin{array}{l}\text { Information provided by executive budget } \\
\text { analyst validates the accuracy of proposal }\end{array}$} & Rank & 15 & 9 & 13 & 13 & 13 \\
\hline & Mean & 4.00 & 4.89 & 4.56 & 4.22 & 4.34 \\
\hline \multirow{2}{*}{$\begin{array}{l}\text { Proposal carries recommendation of "Do } \\
\text { Pass" from policy committee }\end{array}$} & Rank & 16 & 10 & 14 & 14 & 14 \\
\hline & Mean & 3.94 & 4.89 & 4.56 & 4.11 & 4.24 \\
\hline \multirow{2}{*}{$\begin{array}{l}\text { Budget presentation by agency } \\
\text { representative is clear }\end{array}$} & Rank & 14 & 15 & 10 & 16 & 15 \\
\hline & Mean & 4.06 & 4.67 & 4.67 & 4.00 & 4.24 \\
\hline \multirow{2}{*}{$\begin{array}{l}\text { Proposal is required as part of national } \\
\text { accreditation upon which funding is dependent }\end{array}$} & Rank & 17 & 11 & 2 & 18 & 16 \\
\hline & Mean & 3.83 & 4.78 & 5.22 & 3.78 & 4.21 \\
\hline \multirow{2}{*}{$\begin{array}{l}\text { Proposal otherwise justified does not } \\
\text { require full time equivalents (FTE) }\end{array}$} & Rank & 13 & 24 & 24 & 15 & 17 \\
\hline & Mean & 4.28 & 3.56 & 4.11 & 4.00 & 4.07 \\
\hline \multirow{2}{*}{$\begin{array}{l}\text { Proposal does not require use of state } \\
\text { general fund dollars }\end{array}$} & Rank & 18 & 20 & 16 & 17 & 18 \\
\hline & Mean & 3.83 & 4.22 & 4.33 & 3.78 & 3.97 \\
\hline Proposal is included in the budget & Rank & 21 & 17 & 21 & 20 & 19 \\
\hline proposal of the governor & Mean & 3.39 & 4.44 & 4.33 & 3.44 & 3.83 \\
\hline Proposal is included in budget proposal & Rank & 20 & 21 & 19 & 21 & 20 \\
\hline of governor from own party & Mean & 3.50 & 4.11 & 4.33 & 3.39 & 3.76 \\
\hline Proposal requires $<\$ 100,000$ from state & Rank & 19 & 23 & 24 & 19 & 21 \\
\hline general fund & Mean & 3.61 & 3.67 & 4.11 & 3.50 & 3.69 \\
\hline Proposal is supported by stakeholders & Rank & 22 & 18 & 20 & 22 & 22 \\
\hline & Mean & 3.28 & 4.33 & 4.33 & 3.33 & 3.66 \\
\hline Proposal is required as part of national & Rank & 24 & 19 & 23 & 23 & 23 \\
\hline accreditation upon which funding is not dependent & Mean & 2.94 & 4.22 & 4.11 & 3.11 & 3.45 \\
\hline Agency representative has good speaking & Rank & 23 & 22 & 22 & 24 & 24 \\
\hline skills & Mean & 3.00 & 3.67 & 4.22 & 2.72 & 3.31 \\
\hline Agency representative uses technology to & Rank & 25 & 25 & 25 & 25 & 25 \\
\hline present proposal & Mean & 2.78 & 3.44 & 4.00 & 2.61 & 3.07 \\
\hline Proposal has support of NCSL & Rank & 26 & 26 & 26 & 26 & 26 \\
\hline & Mean & 2.39 & 2.22 & 2.56 & 2.28 & 2.38 \\
\hline Proposal is supported by legislative & Rank & 27 & 27 & 27 & 27 & 27 \\
\hline peers from other states & Mean & 2.11 & 1.67 & 2.44 & 1.78 & 2.07 \\
\hline
\end{tabular}

Note: The mean importance column reflects a Likert scale from 1 (least important) to 6 (most important). 
Table 5

Independent Samples T Tests Comparing Importance Ratings

for Categories of Chamber and Political Party

\begin{tabular}{|c|c|c|c|}
\hline & \multirow[b]{2}{*}{ Mean } & \multicolumn{2}{|c|}{ T-Score } \\
\hline & & Party & Chamber \\
\hline Proposal results in efficiency in state or local government & 5.28 & $\overline{-2.443} *$ & -.808 \\
\hline Proposal addresses a well established need & 5.07 & .000 & -1.210 \\
\hline Legislative fiscal analyst validates accuracy of proposal & 4.90 & -.129 & -1.601 \\
\hline Proposal does not put budget out of balance & 4.83 & .835 & -1.211 \\
\hline Proposal is supported by constituents & 4.76 & 1.272 & -.280 \\
\hline Program with good past performance & 4.72 & -.541 & -.546 \\
\hline Proposal has clear outcome measures related to goals & 4.72 & -.521 & -.929 \\
\hline $\begin{array}{l}\text { Agency has positive relationship of trust and credibility with } \\
\text { legislator }\end{array}$ & 4.69 & 1.645 & -.851 \\
\hline Proposal is equitable to all impacted & 4.62 & .133 & .000 \\
\hline Proposal clearly helps agency accomplish its mission & 4.62 & -.553 & -1.586 \\
\hline Proposal is included in own party leadership strategy & 4.54 & -.763 & -.156 \\
\hline $\begin{array}{l}\text { Proposal addresses issue with which legislator has had } \\
\text { personal experience }\end{array}$ & 4.52 & $2.514^{*}$ & -.801 \\
\hline Executive budget analyst validates accuracy of proposal & 4.34 & .620 & -1.746 \\
\hline Proposal has "Do Pass" recommendation from policy committee & 4.24 & 907 & -2.050 \\
\hline Budget presentation by agency is clear & 4.24 & 1.325 & -1.199 \\
\hline $\begin{array}{l}\text { Proposal is required as part of national accreditation upon } \\
\text { which funding is dependent }\end{array}$ & 4.21 & $3.195^{* *}$ & -1.926 \\
\hline Proposal otherwise justified does not require FTE & 4.07 & .199 & 1.336 \\
\hline Proposal does not require use of state general fund dollars & 3.97 & 1.220 & -.841 \\
\hline Proposal is included in the budget proposal of the governor & 3.83 & 1.533 & -1.856 \\
\hline $\begin{array}{l}\text { Proposal is included in budget proposal of governor from own } \\
\text { party }\end{array}$ & 3.76 & 1.779 & -1.111 \\
\hline Proposal requires $<\$ 100,000$ from state general fund & 3.69 & 1.295 & -.116 \\
\hline Proposal is supported by stakeholders & 3.66 & 1.846 & -2.004 \\
\hline $\begin{array}{l}\text { Proposal is required as part of national accreditation upon } \\
\text { which funding not dependent }\end{array}$ & 3.45 & 1.756 & $-2.401 *$ \\
\hline Agency representative has good speaking skills & 3.31 & $2.734 *$ & -1.091 \\
\hline Agency representative uses technology & 3.07 & $2.680^{*}$ & -1.213 \\
\hline Proposal has support of NCSL & 2.38 & .526 & .316 \\
\hline Proposal is supported by legislative peers from other states & 2.07 & 1.690 & 1.116 \\
\hline
\end{tabular}

Note: $* \mathrm{p}<.05 ;{ }^{* *} \mathrm{p}<.01$; The mean importance column reflects a Likert scale from 1 (least important) to 6 (most important). A positive $t$ value for Party indicates that Democrats rated the factor as more important, and vice-versa. 
Table 6

Difference Scores Comparing Importance for Legislators with Ability to Impact by Agency

\begin{tabular}{lccc} 
& Mean Importance & Mean Impact \\
& Legislators & Agency & Diff. \\
\hline Proposal results in efficiency in state or local government & 5.28 & 4.89 & 0.39 \\
Proposal addresses a well established need & 5.07 & 5.17 & -0.10 \\
Legislative fiscal analyst validates accuracy of proposal & 4.90 & 4.17 & 0.73 \\
Proposal does not put budget out of balance & 4.83 & 3.92 & 0.91 \\
Proposal is supported by constituents & 4.76 & 4.29 & 0.47 \\
Program with good past performance & 4.72 & 4.85 & -0.13 \\
Proposal has clear outcome measures related to goals & 4.72 & 5.08 & -0.36 \\
Agency has positive relationship of trust and credibility with legislator & 4.69 & 5.2 & -0.51 \\
Proposal is equitable to all impacted & 4.62 & 5.28 & -0.66 \\
Proposal clearly helps agency accomplish its mission & 4.62 & 4.46 & 0.16 \\
Proposal is included in own party leadership strategy & 4.54 & 3.59 & 0.95 \\
Proposal addresses issue with which legislator has had personal experience & 4.52 & 3.9 & 0.62 \\
Executive fiscal analyst validates accuracy of proposal & 4.34 & 1.26 & -0.03 \\
Proposal has "Do Pass" recommendation from policy committee & 4.24 & 4.24 & 0.00 \\
Budget presentation by agency is clear & 4.24 & 5.38 & -1.14 \\
Proposal is required as part of national accreditation upon which funding is dependent & 4.21 & 3.42 & 0.79 \\
Proposal otherwise justified does not require FTE & 4.07 & 4.03 & 0.04 \\
Proposal does not require use of state general fund dollars & 3.97 & 4.2 & -0.23 \\
Proposal is included in the budget proposal of the governor & 3.83 & 4.49 & -0.66 \\
Proposal is included in budget proposal of governor from own party & 3.76 & 3.90 & -0.14 \\
Proposal requires $<\$ 100,000$ from state general fund & 3.69 & 3.76 & -0.07 \\
Proposal is supported by stakeholders & 3.66 & 4.69 & -1.03 \\
Proposal is required as part of national accreditation upon which funding not dependent & 3.45 & 3.06 & 0.39 \\
Agency representative has good speaking skills & 3.31 & 4.80 & -1.49 \\
Agency representative uses technology & 3.07 & 3.97 & -0.90 \\
Proposal has support of NCSL & 2.38 & 2.14 & 0.24 \\
Proposal is supported by legislative peers from other states & 2.07 & 1.80 & 0.27
\end{tabular}

Notes: The mean importance column reflects a Likert scale from 1 (least important) to 6 (most important). The mean impact column reflects a Likert scale from 1 (least impact) to 6 (most impact). A "difference" of zero indicates that importance and ability to impact are the same; a positive "difference" score indicates that importance to legislators is rated higher than ability to impact, and vice-versa. 